Didaché: Journal of Christian Education

Vol. 1, No. 2 (2020): 205-221

journal.sttsimpson.ac.id/index.php/DJCE

e-ISSN: $2722-8584$

\title{
Kompetensi Guru Sekolah Minggu Terhadap Keefektifan Mengajar Anak: Suatu Studi Kuantitatif Di Jemaat GPdI El-Shaddai Makassar
}

\author{
Ivana IT Tefbana, Sarce Rien Hana, Tri Supartini, Hengki Wijaya \\ Sekolah Tinggi Filsafat Jaffray Makassar \\ Email: ivanatefbana@gmail.com
}

\begin{abstract}
Teacher competence is one of the factors causing the creation of teaching effectiveness. An educator's success is effectively produces students who can take advantage of knowledge and lessons in everyday life. In the Sunday school commission, teachers who are competent in teaching are also needed. Even though the teaching staff or teachers who teach are not professionals, they should have quality teaching standards. The purpose of writing this thesis is to determine the extent of the influence of the competence of Sunday school teachers on the effectiveness of teaching children in the GPdI El-Shaddai church, Makassar. The author uses this type of quantitative research using a questionnaire and conducting interviews via telephone addressed to teachers, administrators, evangelicals in the GPdI El-Shaddai Makassar congregation. From the research that has been done, it can be concluded that: 1) The competence of Sunday school teachers greatly affects the effectiveness of children's teaching. 2) Increasing teacher competence is obtained through training and evaluation, which are held annually. 3) a Sunday school teacher must be a role model and must first provide a good and right example to his students. 4) teaching aids and study rooms, and other supporting media are needed during the teaching process.
\end{abstract}

Keywords: Competence, Teacher, Effectiveness, Teaching, Sunday School Children.

\begin{abstract}
Abstrak
Kompetensi guru merupakan salah satu faktor penyebab terciptanya keefektifan mengajar. Keefektifan mengajar dari seorang tenaga pendidik dapat dilihat dari keberhasilanya menghasilkan murid yang mengaktualisasikan ilmu dan pelajaran yang didapatkannya dalam kehidupan sehari-hari. Ternyata di komisi sekolah minggu, juga sangat dibutuhkan seorang guru yang memiliki kompetensi dalam mengajar. Sekalipun tenaga pendidik atau guru yang mengajar bukanlah seorang professional, namun setidaknya punya standar mengajar yang bermutu. Tujuan penulisan ini adalah untuk mengetahui sejauh mana pengaruh kompetensi guru Sekolah Minggu terhadap keefektifan mengajar anak di jemaat GPdI El-Shaddai Makassar. Penulis menggunakan jenis penelitian kuantitatif dengan menggunakan angket dan melakukan wawancara lewat via telepon yang ditujukan kepada guru-guru, pengurus, Evangelis yang ada di jemaat GPdI El-Shaddai Makassar. Dari penelitian yang telah dilakukan maka dapat
\end{abstract}


diperoleh kesimpulan bahwa: 1) Kompetensi guru Sekolah Minggu sangat mempengaruhi keefektifan mengajar anak. 2) Peningkatan kompetensi guru diperoleh melalui pelatihan dan evaluasi yang diadakan setiap tahunnya. 3) seorang guru Sekolah Minggu harus bisa menjadi teladan dan harus terlebih dahulu memberikan contoh yang baik dan benar kepada muridnya. 4) alat peraga dan ruang belajar serta media pendukung lainnya sangat dibutuhkan selama proses mengajar.

Kata kunci:Kompetensi, Guru, Keefektifan, Mengajar, Anak, Sekolah Minggu.

\section{Pendahuluan}

Anak Sekolah Minggu adalah pusat pelayanan dalam sebuah gereja, sebab nantinya anak akan menjadi generasi penerus gereja baik untuk masa kini dan dimasa yang akan datang. Gereja harus mempersiapkan anak dengan baik untuk menjadi anggota gereja yang siap dan memiliki pemahaman yang benar, dan mendorong anak-anak untuk menjadi pemimpin bagi generasi gereja di waktu yang akan datang. Richards (2013) mendefinisikan gereja adalah salah satu komunitas yang baik untuk anak bisa bertumbuh dan berkembang, karena anak harus dibesarkan sebagai bagian dalam sebuah komunitas yang penuh kasih dan kudus. Sekolah Minggu hadir sebagai lembaga gereja untuk menolong anak mengenal siapa Tuhan Yesus dalam kehidupan iman percaya mereka. Tugas dalam mendidik anak bukan hanya menjadi tanggung jawab keluarga dan sekolah tetapi juga gereja. Dalam gereja bukan hanya pendeta atau gembala yang sangat berpengaruh dalam membantu mendidik anak tetapi juga guru-guru Sekolah Minggu yang ada. Gereja harus mempersiapkan anak-anak sebagai anggota gereja, oleh sebab itu guru Sekolah Minggu sangat berpengaruh dalam Pelayanan Anak.

Sekolah Minggu membutuhkan seorang guru yang berkompeten. Kristiono dan Perdana (2019) berpendapat "Untuk menjadi seorang guru Sekolah Minggu tidak saja dituntut memiliki pengetahuan teologi tetapi juga dituntut memiliki kompetensi di bidang pengajaran, di sisi lain guru sekolah minggu juga harus mampu menjadi teladan dan memiliki relasi yang harmonis dengan anak-anak." Namun masalah lain muncul dalam gereja karena kebanyakan anggota jemaat tidak ingin menjadi seorang guru Sekolah Minggu. Ada yang beralasan karena tidak punya waktu, atau tidak terlalu suka dengan anak-anak, tidak punya karunia dalam bidang tersebut dan lain sebagainya. Ketidaksanggupan jemaat dalam mengambil bagian dalam pelayanan merupakan beban tersendiri bagi gereja. Disisi lain guru Sekolah Minggu harus 
menjadi teladan dan memiliki hubungan yang harmonis dengan anak sekolah minggu.

Gereja perlu menyiapkan guru sekolah minggu dengan empat kompetensi dasar yaitu kompetensi sosial, kompetensi personal (kepribadian), kompetensi profesional, dan kompetensi pedagogik (Kristiono \& Perdana, 2019). Empat kompetensi dasar ini harus diketahui dan dimiliki oleh guru-guru Sekolah Minggu yang mengajar. Pada umumnya, disetiap gereja-gereja yang ada, guru sekolah minggu terdiri dari anak-anak muda dan orang dewasa. Semakin banyak anak-anak Sekolah Minggu dalam gereja maka guru Sekolah Minggupun yang mengajar harus seimbang dengan jumlah anak-anak. Selain itu guru yang mengajar sebaiknya memiliki kesukaan terhadap anak-anak. Hal ini sangat penting untuk membangun hubungan yang baik bagi anak-anak yang nantinya akan dilayani. Seorang guru yang matang akan memiliki kepercayaan diri jika ia telah mendapatkan pelatihan dan pengalaman yang cukup (Gunarsa \& Gunarsa, 2017, p. 135). Sebab seiring perkembangan zaman kemampuan mengajar guru terhadap murid yang diajar sangat perlu untuk diperhatikan kualiatasnya, bukan hanya kuantitasnya tetapi kualitas juga adalah hal penting yang harus diperhatikan.

Banyak kendala yang dihadapi oleh guru Sekolah Minggu. Bukan hanya kendala dengan proses belajar mengajar tetapi juga kendala dengan diri sendiri. Tantangan dari luar dan dalam diri seorang guru Sekolah Minggu menjadi pertimbangan yang sangat penting dalam kehidupan pelayanan. Persiapan yang matang mempengaruhi pelayanan seseorang. Persiapan yang matang dari para guru Sekolah Minggu pada saat pelayanan anak akan terlihat dari hasilnya. Namun pada kenyataannya, berbanding terbalik dari apa yang diharapkan. Maka dari itu baik pemimpin dan guru-guru Sekolah Minggu harus berusaha dengan sekuat tenaga untuk menghilangkan halangan-halangan yang menyebabkan perubahan itu tidak terjadi (Ronda, 2011). Setiap tenaga pendidik baik disekolah maupun digereja harus berusaha meningkatkan kuliatas pengajarannya untuk sebuah perubahan positif yang membangun dan mendidik anak untuk mengalami pertumbuhan yang benar.

Salah satu hal yang dibutuhkan untuk meningkatkan kualitas pengajaran di lembaga pelayanan Sekolah Minggu adalah kedisiplinan dalam mempersiapkan materi. Kristiono dan Perdana (2019), “Kedisiplinan adalah syarat mutlak bagi seorang guru serta dalam tugas mengajar, guru tidak boleh datang terlambat supaya materi dapat tersampaikan dengan baik dan efektif." Bukan 
hanya sampai disitu tetapi juga hasil dari proses belajar mengajar perlu ada yang namanya laporan evaluasi. Guru harus menguasai dan memaknai materi yang diajarkan kepada anak Sekolah Minggu. Guru juga harus mengetahui kondisi yang berkembang dari anak. Perihal apa yang anak-anak sukai pada masa-masa tumbuh kembang mereka. Betul-betul harus memperhatikan yang disukai anak.

Dalam gereja anak-anak sepertinya dilayani dengan baik, tetapi apakah mereka mengalami pertumbuhan rohani yang baik dan benar sesuai dengan firman Tuhan. Anak-anak harus dididik sesuai dengan apa kata firman Tuhan sebagaimana yang tercatat dalam kitab Amsal 3:11-12 "Hai anakku, janganlah engkau menolak didikan Tuhan, dan janganlah engkau bosan akan peringatanNya. Karena Tuhan memberi ajaran kepada yang dikasihi-Nya, seperti seorang ayah kepada anak yang dikasihi-Nya." Tuhan mau anak-anak-Nya bertumbuh dalam pengajaran yang benar dan dalam komunitas yang sehat. Guru Sekolah Minggu salah satu tenaga pendidik yang dapat menolong anak Sekolah Minggu untuk bertumbuh dalam pengajaran yang benar.

Seorang guru Sekolah Minggu dan anak yang dilayani harus memiliki komunikasi dan membangun hubungan yang baik bagaikan sahabat. Guru Sekolah Minggu harus dapat dipercaya, karena banyak anak-anak sekolah minggu yang sebenarnya sangat membutuhkan peran seorang guru Sekolah Minggu di GPdI El-Shaddai Makassar. Banyak anak-anak yang mengalami masalah tertentu dan sepertinya ia membutuhkan teman untuk bercerita, tetapi terkadang mereka tidak mempunyai seesorang yang dapat dipercaya untuk berbagi mengenai apa yang dialami. Oleh sebab itu peranan guru Sekolah Minggu harus terealisasi dengan benar, punya persiapan yang matang untuk melayani anak-anak yang memiliki masalah-masalah tertentu.

Dibutuhkan kerja sama yang baik untuk memajukan pelayanan anak, oleh sebab itu kompetenesi yang dimiliki oleh seorang guru sangat berpengaruh pada keefektifan mengajarnya. Dalam lingkup gereja guru mendidik anak Sekolah Minggu untuk mengalami pertumbuhan rohani yang benar. Juanda (2016), seorang guru yang matang akan memiliki kepercayaan diri jika ia telah mendapatkan pelatihan dan pengalaman yang cukup. Guru Sekolah Minggu di GPdI El-Shaddai tidak boleh hanya melihat dari sisi anak sudah dilayani, tetapi juga harus melihat pertumbuhan rohani yang nyata pada anak, apakah anak sekolah minggu yang selama dibimbing betul-betul mengalami pertumbuhan yang bukan hanya sekedar baik tetapi mengalami pertumbuhan rohani yang benar. Komisi Sekolah Minggu harus mengadakan evaluasi untuk dapat menilai 
hasil pelayanan, karena jika ada yang salah perlu diperbaiki sesegera mungkin demi kenyamanan dan kebaikan bersama.

Untuk dapat menolong terciptanya pelayanan yang baik pada anak-anak maka kompotensi guru Sekolah Minggu terhadap keefektifan mengajar anak di jemaat GPdI El-Shaddai Makassar sangat diperlukan, ketua komite Sekolah Minggu dan gembala sidang yang ada harus memperhatikan hal ini. Latif (2017), berpendapat bahwa anak Sekolah Minggu, mereka akan menjadi generasi-generasi penerus gereja yang kuat serta mengasihi Tuhan, memiliki komitmen tidak mudah terpengaruh, menjadikan firman Tuhan sebagai pedoman hidupnya dan yang membawa dampak yang baik bagi lingkungan dimana mereka berada. Dengan demikian dapat simpulkan bahwasebuah pelayanan kepada anak dapat dianggap berhasil apabila semua pihak mengetahui perannya dengan baik. Khususnya pendidik yaitu gembala sidang dan guru-guru Sekolah Minggu mengetahui perannya. Sebuah objek pelayanan yang tampaknya sering dilayani dengan baik belum tentu mengalami pertumbuhan rohani yang baik dan benar.

Untuk dapat menolong anak memenuhi harapan yang ada, maka seorang guru Sekolah Minggu harus memiliki kompetensi mengajar berdasarkan standar kebijakan nasional. Jika dalam gereja anak-anak kurang aktif mengikuti pelayanan atau menutup diri, baiklah guru Sekolah Minggu mendorong anak-anak untuk terlibat dalam pelayanan yang ada, memotivasi bahwa mereka juga bisa. Sabdono (2016, pp. 67-68), proses mengalami perubahan dalam ketaatan kepada Tuhan Yesus merupakan ciri utama orang Kristen. Betapa pentingnya untuk mengajarkan anak Sekolah Minggu hidup dalam iman percaya yang benar kepada Tuhan Yesus.

Sebagai pembina kerohanian maka gembala sidang dan para guru Sekolah Minggu yang ada, harus membahas masalah ini dengan baik. Mencari solusi bagaimana pelayanan anak yang ada bisa meningkat dan mengalami pertumbuhan rohani yang benar sesuai dengan firman Tuhan. Jika perlu gereja mengundang Tim Pelayanan Anak untuk membekali guru-guru Sekolah Minggu, sehingga memiiki pengetahuan dan pemahaman yang benar mengenai cara melayani anak dan yang menjadi kebutuhan anak. Karena hal ini akan sangat membantu, apalagi dengan jumlah guru yang sangat banyak dan memiliki pos Sekolah Minggu yang banyak pula maka hal ini menjadi tanggungjawab yang besar, untuk bekerjasama dengan baik menerapkan pelay anan yang nyata dan benar untuk menghasilkan guru-guru Sekolah Minggu yang berperan aktif da- 
lam membantu pertumbuhan rohani pada anak di jemaat GPdI El-Shaddai Makassar.

Perkembangan zaman dan kemajuan tekhnologi menuntut seorang anak Sekolah Minggu untuk menjadi gerenarasi yang berkarakter dan cerdas. Tetapi dalam proses untuk menciptakan generasi yang berhasil dan matang tidak semudah yang dibayangkan. Banyak hal yang menghalangi harapan tersebut. Banyak masalah yang muncul, salah satu masalah yang timbul adalah proses mengalami perubahan dalam ketaatan kepada Tuhan Yesus merupakan ciri utama orang Kristen (Rosdiana, 2013). Masalah yang dihadapi guru adalah menghadapi banyak kendala dalam menjalankan tugasnya dalam pelayanan Sekolah Minggu atau secara personal (Kristiono \& Perdana, 2019). Disisi lain fakta-fakta yang muncul beraneka ragam.

Beberapa fakta yang muncul dalam proses belajar mengajar diantaranya yaitu: proses belajar mengajar ada variatif tetapi cenderung menoton, respons peserta didik cenderung kurang positif, aktivitas yang dilakukan dalam proses belajar mengajar kurang bervariasi, hasil belajar yang diperoleh belum dijadika tolak ukur untuk langkah berikutnya. Memerhatikan fakta yang ada maka hal tersebut dapat saja terjadi pada anak kelas lain yang pembelajarannya dilakukan belum efektif. Yusuf (2018) mengungkapkan bahwa kegiatan belajar mengajar tergolong komunukatif, tepat sasaran dan tercapai tujuan secara maksimal merupakan keefektifan suatu proses belajar mengajar.

Inilah juga masalah yang dihadapi oleh guru Sekolah Minggu di GPdI ElShaddai Makassar. Banyak guru mengalami masalah dalam proses mengajar. Banyak guru yang tidak terlatih mengajar anak-anak sehingga kebanyakan guru mengajar tidak mempersiapkan bahan ajar dengan baik. Mengapa demikian karena seharusnya setiap tenaga pengajar guru sekolah minggu di gereja tersebut harus mempunyai kompetensi salah satunya dengan mengikuti pelatihan menjadi seorang guru Sekolah Minggu. Guru Sekolah Minggu yang tidak mempunyai kompetensi sangat berpengaruh terhadap keefektifan mengajar anak. Yusuf (2018) berpendapat efektivitas adalah suatu perubahan yang membawa dampak, makna dan manfaat tertentu. Ciri dari belajar efektif adalah mengedepankan inisiatif memberdayakan siswa. Kristiono dan Perdana (2019), Sekolah Minggu harus mampu mendidik anak-anak Sekolah Minggu agar dapat beradaptasi sepenuhnya di masa pertumbuhannya.

Setiap masalah pasti ada jalan keluarnya atau solusi. Dari permasalahan di atas maka solusi yang dapat diterapkan adalah seorang guru Sekolah Minggu 
tidak saja dituntut memiliki pengetahuan teologi tetapi juga dituntut memiliki kompetensi dibidang pengajaran, di sisi lain guru Sekolah Minggu jugaharus mampu menjadi teladan dan memiliki relasi yang harmonis dengan anak-anak. Gereja perlu menyiapkan guru-guru Sekolah Minggu dengan empat kompetensi yang harus dimiliki, yaitu kompetensi Pedagogik, kepribadian, sosial dan professional. Bahkan Alkitab menuliskan dalam Yakobus 3:1 "Saudara-saudaraku, janganlah banyak orang diantara kamu mau menjadi guru, sebab kamu tahu bahwa sebagai guru kamu dihakimi menurut ukuran yang lebih berat." Ayat ini memberikan pemahaman bahwa menjadi guru Sekolah Minggu merupakan tugas dan tanggung jawab yang tidak mudah, harus dilakukan dengan sungguh-sungguh karena keterbatasan kompetensi. Kompetensi guru Sekolah Minggu menjadi penting dalam pelayanan anak. Tulisan ini bertujuan untuk menjelaskan pengaruh kompetensi guru Sekolah Minggu terhadap keefektifan mengajar anak dalam jemaat gereja.

\section{Metode}

Metode penelitian yang penulis gunakan didalam penyusunan ini adalah penelitian kuantitatif dengan tehnik pengumpulan data melalui kajian pustaka, observasi, penggunaan kuesioner (angket) dan wawancara. Penelitian ini dilakukan di GPdI El-Shaddai Makassar yang beralamat di Jalan Poros Perintis Kemerdekaan tepat depan Yonif 700 Rider.

Populasi dalam penelitian ini adalah guru-guru Sekolah Minggu GPdI ElShaddai Makassar yang berjumlah 75 orang dan sampel yang diambil hanya 10 orang. Dalam penelitian ini variabel $X$ adalah kompetensi guru Sekolah Minggu sedangkan yang menjadi variabel $Y$ adalah keefektifan mengajar anak di jemaat GPdI El-Shaddai Makassar. Dalam penelitian ini digunakan tehnik pengumpulan data yang dianggap cocok yaitu penggunaan kuesioner (angket). "Kuesioner (angket) adalah pertanyaan tertulis yang diberikan kepada subjek yang ditelitiuntuk mengumpulkan informasi yang dibutuhkan oleh peneliti," Teknik ini merupakan teknik pengumpulan data dengan menyerahkan atau mengirimkan daftar pertanyaan untuk diisi responden secara online lewat google form (Wijaya, 2017, p. 69).

Variabel X yaitu kompetensi guru Sekolah Minggu memiliki 4 indikator yaitu kompetensi pedagogik, kompetensi kepribadian, pentingnya kompetensi guru dan peningkatan kompetensi guru. Sedangkan variabel Y yaitu keefektifan mengajar anak di jemaat GPdI El-Shaddai Makassar memiliki 3 indikator yaitu 
metode, media dan guru yang efektif. data yang terkumpul akan dianalisis dengan menggunakan Untuk menentukan hasil serta jumlah persentase yang diperoleh menggunakan rumus Skala Likert sebagai berikut:

$\%=\frac{n}{N} x 100$

Keterangan:

$\%=$ Persentase

$\mathrm{n}$ = Nilai yang diperoleh (Jumlah Jawaban Responden)

$\mathrm{N}=$ Jumlah Responden

Selain itu penulis melakukan wawancara ketika membutuhkan informasi terkait pertnyaan angket. Usman dan Akbar (2008, p. 58), “Wawancara merupakan Tanya jawab lisan antara dua orang atau lebih secara langsung untuk memperoleh data yang lengkap dan menguji hasil pengumpulan data lainnya." Wawancara ini dilakukan untuk mendapatkan data akurat terkait pertanyaan angket yang nantinya membutuhkan informasi yang cukup dari alasan para responden. Wawancara ini untuk menanyakan kepada responden alasan mereka menjawab tidak pada soal pertanyaan yang ditujukan di dalam tabel angket.

\section{Hasil dan Pembahasan}

\section{Analisis Hasil dan Pembahasan}

Hasil penelitian terdiri atas dua indikator kompetensi guru terdiri atas kompetensi pedagogik, dan kepribadian yang diuji dalam tulisan ini. Kuesioner yang dibagikan kepada 10 guru secara acak untuk melihat kemampuan pedagogik, dan kepribadian guru.

Tabel 1. Kompetensi Pedagogik

\begin{tabular}{llllllll}
\hline \multirow{2}{*}{ No } & \multicolumn{1}{c}{ Pertanyaan } & \multicolumn{2}{c}{ Ya } & \multicolumn{2}{c}{ Tidak } & \multicolumn{2}{c}{ Jumlah } \\
\cline { 2 - 7 } & $\mathrm{n}$ & $\%$ & $\mathrm{n}$ & $\%$ & $\mathrm{~N}$ & $\%$ \\
\hline $\begin{array}{l}\text { Apakah anda memiliki } \\
\text { pengetahuan dalam hal } \\
\text { mengajar sekolah }\end{array}$ & 10 & 100 & 0 & 0 & 100 & 100 \\
& & & & & & & \\
minggu? & $\begin{array}{l}\text { Apakah anda tahu sejauh } \\
\text { mana pemahaman }\end{array}$ & 9 & 90 & 1 & 10 & 10 & 100 \\
\hline & & & & & & \\
\hline
\end{tabular}




\begin{tabular}{|c|c|c|c|c|c|c|c|}
\hline 3 & $\begin{array}{l}\text { Apakah anda mampu } \\
\text { membuat silabus? }\end{array}$ & 6 & 60 & 4 & 40 & 10 & 100 \\
\hline 4 & $\begin{array}{l}\text { Apakah anda memahami } \\
\text { isi dan meteri yang akan } \\
\text { diajarkan di sekolah } \\
\text { minggu? }\end{array}$ & 9 & 90 & 1 & 10 & 10 & 100 \\
\hline 5 & $\begin{array}{l}\text { Apakah anda mendorong } \\
\text { anak sekolah minggu } \\
\text { untuk } \\
\text { mengaktualisasikan } \\
\text { kemampuan yang } \\
\text { dimilikinya? }\end{array}$ & 10 & 100 & 0 & 0 & 10 & 100 \\
\hline
\end{tabular}

Pada tabel 1 terlihat guru memiliki pengetahuan dalam mengajar Sekolah Minggu, dan guru mampu memotivasi siswa untuk mengaktualisasikan kemampuan yang dimilikinya. Tabel 1 juga menunjukkan 90\% guru memahami perkembangan belajar siswa. Guru juga mengetahui isi dan materi yang disampaikan kepada siswa. Hanya ada $60 \%$ yang memahami pembuatan silabus. Berdasarkan penelitian Susilawati \& An (2017, pp. 365-366), permasalahan yang sama dialami mahasiswa yang sudah belajar pembuatan silabus, tetapi ketika diberi penugasan untuk membuat silabus maka didapati tidak sesuai dengan prosedur. Untuk itu guru Sekolah Minggu perlu berlatih dan mengikuti pelatihan pembuatan silabus, atau menonton tutorial pembuatan silabus.

Kompetensi pembuatan silabus ini dikategorikan sebagai kompetensi sosial yaitu kompetensi guru dalam berinteraksi sosial baik dengan siswa dan sarana prasarana termasuk dalam membuat silabus dibutuhkan fasilitas internet, bahan bacaan elektronik, dan penguasaan media pembelajaran (Astika \& Bunga, 2016).

Tabel 2. Kompetensi Kepribadian

\begin{tabular}{llllllll}
\hline \multirow{2}{*}{ No } & \multirow{2}{*}{ Pertanyaan } & \multicolumn{2}{c}{ Ya } & \multicolumn{2}{c}{ Tidak } & \multicolumn{2}{c}{ Jumlah } \\
\cline { 2 - 8 } & $\mathrm{n}$ & $\%$ & $\mathrm{n}$ & $\%$ & $\mathrm{~N}$ & $\%$ \\
\hline \multirow{2}{*}{$\begin{array}{l}\text { Apakah anda bersikap } \\
\begin{array}{l}\text { dewasa dalam } \\
\text { bertindak? }\end{array}\end{array}$} & 10 & 100 & 0 & 0 & 10 & 100
\end{tabular}



Apakah anda
terlebih dahulu kepada
anak sekolah minggu?
2 memberikan sapaan
990
110
10
100

Tabel 2 terlihat hasilnya guru Sekolah Minggu menunjukkan kepribadian yang baik. Guru Sekolah Minggu tentunya diharapkan dapat melakukan sikap yang baik. Dalam silabus pembelajaran tertuang sikap spiritual dan sikap sosial. Sikap sosial juga mencerminkan kepribadian guru seperti kejujuran, disiplin, peduli, tanggung jawab, sikap sosial lainnya (Wijaya et al., 2020), dan karakter Kristen yang baik sesuai dengan firman Tuhan (Sidjabat, 2019).

Tabel 3. Pentingnya Kompetensi Guru

\begin{tabular}{|c|c|c|c|c|c|c|c|}
\hline \multirow{2}{*}{ No } & \multirow{2}{*}{ Pertanyaan } & \multicolumn{2}{|c|}{ Ya } & \multicolumn{2}{|c|}{ Tidak } & \multicolumn{2}{|c|}{ Jumlah } \\
\hline & & $\mathrm{n}$ & $\%$ & $\mathrm{n}$ & $\%$ & $\mathrm{~N}$ & $\%$ \\
\hline \multirow[t]{5}{*}{1} & Setujukah saudara jika & & & & & & \\
\hline & calon guru yang akan & & & & & & \\
\hline & $\begin{array}{l}\text { mengajar harus } \\
\text { diseleksi kemampuan }\end{array}$ & 8 & 80 & 2 & 20 & 10 & 100 \\
\hline & mengajarnya terlebih & & & & & & \\
\hline & dahulu? & & & & & & \\
\hline
\end{tabular}

Tabel 3 menujukkan perlu calon guru Sekolah Minggu diseleksi kemampuan mengajar (pedagogik). Pelayanan Sekolah Minggu adalah pelayanan untuk memuliakan Tuhan. Bila guru dituntut professional pada sekolah formal maka sekolah informal seperti Sekolah Minggu pun harusnya lebih baik lagi karena mengajarkan firman Tuhan dan mendidik anak-anak untuk lebih mengenal Tuhan.

Table 4. Peningkatan Kompetensi Guru

\begin{tabular}{llllllll}
\hline \multirow{2}{*}{ No } & \multicolumn{1}{c}{ Pertanyaan } & \multicolumn{2}{c}{ Ya } & \multicolumn{2}{c}{ Tidak } & \multicolumn{2}{c}{ Jumlah } \\
\cline { 2 - 8 } & $\mathrm{n}$ & $\%$ & $\mathrm{n}$ & $\%$ & $\mathrm{~N}$ & $\%$ \\
\hline \multirow{2}{*}{1} & $\begin{array}{l}\text { Apakah anda } \\
\text { mengikuti pelatihan } \\
\text { sekolah minggu untuk } \\
\text { meningkatkan }\end{array}$ & 6 & 60 & 4 & 40 & 10 & 100 \\
\hline
\end{tabular}




\begin{tabular}{|c|c|c|c|c|c|c|c|}
\hline & $\begin{array}{l}\text { kemampuan dalam hal } \\
\text { mengajar anak? }\end{array}$ & & & & & & \\
\hline 2 & $\begin{array}{l}\text { Apakah anda } \\
\text { mengadakan evalasi } \\
\text { pada saat mengajar } \\
\text { sekolah minggu? }\end{array}$ & 10 & 100 & 0 & 0 & 10 & 100 \\
\hline
\end{tabular}

Tabel 4 menunjukkan bahwa masih ada guru Sekolah Minggu yang tidak mengikuti pelatihan Sekolah Minggu sebanyak 40\%. Gereja wajib mewa-dahi pelatihan Sekolah Minggu untuk meningkatkan kemampuan dan latihan mengajar Sekolah Minggu. Guru Sekolah Minggu tentunya berbeda dengan mengajar anak di sekolah formal. Guru Sekolah Minggu mengajarkan firman Tuhan, dan wajib disampaikan dengan baik supaya anak-anak dapat memahaminya dengan baik.

Table 5. Metode mengajar Sekolah Minggu yang Efektif

\begin{tabular}{|c|c|c|c|c|c|c|c|}
\hline \multirow{2}{*}{ No } & \multirow{2}{*}{ Pertanyaan } & \multicolumn{2}{|c|}{$\mathrm{Ya}$} & \multicolumn{2}{|c|}{ Tidak } & \multicolumn{2}{|c|}{ Jumlah } \\
\hline & & $\mathrm{n}$ & $\%$ & $\mathrm{n}$ & $\%$ & $\mathrm{~N}$ & $\%$ \\
\hline 1 & $\begin{array}{l}\text { Metode mengajar } \\
\text { bernyanyi sambil } \\
\text { memperagakan gerak, } \\
\text { apakah anda } \\
\text { menggunakannya? }\end{array}$ & 10 & 100 & 0 & 0 & 10 & 100 \\
\hline 2 & $\begin{array}{l}\text { Apakah anak sekolah } \\
\text { minggu aktif ketika } \\
\text { anda mengajar } \\
\text { menggunakan metode } \\
\text { tanya jawab? }\end{array}$ & 10 & 100 & 0 & 0 & 10 & 100 \\
\hline
\end{tabular}

Dalam mengajar anak dengan efektik maka dibutuhkan juga metode mengajar Sekolah Minggu yang efektif. Pada tabel 5, metode mengajar yang digunakan adalah mengajar bernyayi lagu firman Tuhan sambil memperagakan gerak (Febriyona et al., 2019; Supartini, 2020), dan metode tanya jawab seperti guru bertanya kepada siswa Sekolah Minggu mengenai firman Tuhan, dan siswa Sekolah Minggu yang menjawab akan mendapatkan hadiah. 
Tabel6. Media pendukung keefektifan mengajar

\begin{tabular}{lllllll}
\multirow{2}{*}{ No } & \multicolumn{1}{c}{ Pertanyaan } & \multicolumn{2}{c}{ Ya } & \multicolumn{2}{c}{ Tidak } & \multicolumn{2}{c}{ Jumlah } \\
\cline { 2 - 7 } & $\mathrm{n}$ & $\%$ & $\mathrm{n}$ & $\%$ & $\mathrm{~N}$ & $\%$ \\
\hline \multirow{2}{*}{$\begin{array}{l}\text { Apakah anda } \\
\text { menggunakan alat } \\
\text { peraga pada saat } \\
\text { mengajar sekolah } \\
\text { minggu? }\end{array}$} & 8 & 80 & 2 & 20 & 10 & 100 \\
\hline $\begin{array}{l}\text { Apakah ruangan belajar } \\
\text { sekolah minggu saat ini } \\
\text { perlu dihias sehingga } \\
\text { menarik dan nyaman? }\end{array}$ & 8 & 80 & 2 & 20 & 10 & 100 \\
\hline
\end{tabular}

Pada tabel 6, guru Sekolah Minggu menggunakan alat peraga sebagai alat bantu menjelaskan firman Tuhan. Biasanya menggunakan alat peraga panggung boneka, boneka tangan, alat gambar, dan juga yang saat ini lagi berkembang dengan menggunakan film Superbook (Bayoe et al., 2019). Kondisi kelas Sekolah Minggu yang dihias dan sesuai dengan usia anak-anak memberikan ruang bermain pada anak lebih nyaman. Ruangan Sekolah Minggu harus ramah anak supaya anak-anak dapat menikmati permainan, firman Tuhan dan bermain sambil belajar. Gereja sepatutnya memiliki ruangan khusus untuk pelayanan Sekolah Minggu (Supartini, 2017).

Table 7. Guru yang Efektif

\begin{tabular}{|c|c|c|c|c|c|c|c|}
\hline \multirow{2}{*}{ No } & \multirow{2}{*}{ Pertanyaan } & \multicolumn{2}{|c|}{$\mathrm{Ya}$} & \multicolumn{2}{|c|}{ Tidak } & \multicolumn{2}{|c|}{ Jumlah } \\
\hline & & $\mathrm{n}$ & $\%$ & $\mathrm{n}$ & $\%$ & $\mathrm{~N}$ & $\%$ \\
\hline 1 & $\begin{array}{l}\text { Apakah anda seorang } \\
\text { guru sekolah minggu } \\
\text { yang berkomitmen } \\
\text { melayani anak-anak? }\end{array}$ & 9 & 90 & 1 & 10 & 10 & 100 \\
\hline
\end{tabular}

Tabel 7 menunjukkan hasil yang menggembirakan bahwa guru Sekolah Minggu berkomitmen untuk melayani anak-anak. Hati yang melayani anakanak adalah panggilan mulia. Yesus berkata siapa yang menerima anak-anak ini maka dia pun menerima-Nya. Kata Yesus "Biarkan anak-anak itu datang 
kepada-Ku..." (Markus 10:14). Guru Sekolah Minggu membawa anak-anak datang kepada Tuhan supaya mereka mengalami Tuhan.

\section{Kompetensi Guru Akan Memengaruhi Efektivitas Pengajaran}

Guru yang memiliki kompetensi akan mencapai tujuan pendidikan, dengan memperlihatkan kinerja yang nyata atau kerja professional (Suwanto, 2019, p. 92). Kompetensi guru baik kompetensi pedagogic maupun kepribadian bahkan beberapa kompetensi yang lain sesuai satandar nasional pendidikan sebaiknya dimiliki oleh setiap guru yang hendak akan mengajar karena sebenarnya seorang tenaga pendidik dituntut untuk profesinal dalam bekerja dimana pada saat mendidik memperlihatkan perilaku kerja sesuai dengan harapan dan prestasi yang dimilkinya (Widiyanto \& Darmawan, 2019, pp. 179181). Hasil penelitian menunjukkan bahwa terdapat pengaruh yang sangat singnifikan dari kompetensi guru terhadap keefektifan mengajar anak di jemaat GPdI El-Shaddai Makassar. Hasil tersebut relevan dengan penelitian Widiyanto dan Darmawan (2019), bahwaperlunya perhatian khusus pada peningkatan kompetensi guru. Dari hasil penelitian yang dilakukan bahwa pelatihan, seminar, lesson study, penilaian dan evaluasi hasil kerja dapat menjadi sarana peningkatan kompetensi guru. Pelatihan yang dilaksanakan dalam bentuk pembinaan guru sekolah minggu, inti dasar pengajarannya adalah Yesus sebagai Juruselamat (Riniwati, 2020). Bahkan Darmawan dan Priskila (2020) memperlihatkan bahwa penerapan storytelling merupakan salah satu inovasi pembelajaran pada Sekolah Minggu yang memberi manfaat bagi guru agar dapat meningkatkan kemampuan dalam memahami anak.

Hasil penelitian juga memperlihatkan bahwa tugas seorang tenaga pendidik atau guru Sekolah Minggu tidaklah mudah. Salah satu hal yang menghambat proses belajar megajar anak sekolah minggu pada tahun 2020 adalah adanya pandemic Covid-19. Hal ini menjadi salah satu kendala guru tidak dapat mengajar dengan efektif dan kompetensi guru mengalami penurunan kinerja. Hal ini relevan dengan penelitian yang dilakukan oleh Karnawati dan Mardiharto (2020) bahwa sekolah Minggu pada masa pandemic Covid-19 mengalami berbagai kendala. Oleh sebab itu kompetensi guru tidak dapat disepelehkan karena sangat mempengaruhi kefektifan mengajar dan hasil belajar peserta anak Sekolah Minggu. salah satu solusi yang dapat diterapkan untuk mengetahu keberhasilan dalam mencapai pembelajaran di Sekolah Minggu adalah penilaian berbasis test menurut Saputra (2020). Hasil penelitian menunjukkan $87 \%$ guru 
Sekolah Minggu GPdI El-shaddai Makassar memiliki kompetensi dan hasil memperlihatkan bahwa 88\% kefektifan mengajar tercapai.

\section{Implikasi}

Implikasi untuk guru Sekolah Minggu yang melayanianak-anak adalah: Pertama, seorang guru Sekolah Minggu harus memiliki pengetahuan dalam hal mengajar sekolah minggu, memiliki pemahaman terhadap murid pada saat belajar, dapat membuat silabus, memahami isi materi yang diajarkan, dan mendorong murid untuk mengaktualisasikan kemampuan yang dimiliki merupakan kompetensi pedagogik. Kedua, untuk memiliki kompetensi kepribadian, maka sikap yang harus diterapkan oleh guru sekolah minggu adalah belajar bersikap dewasa dalam bertindak serta guru harus memberikan sapaan terlebih dahulu kepada murid. Ketiga, guru Sekolah Minggu yang hendak akan mengajar harus diseleksi kemampuan mengajarnya terlebih dahulu. Keempat, guru sekolah minggu harus mengikuti pelatihan yang diadakan setiap tahun atau 6 bulan sekali baik itu di gereja sendiri atau yang diadakan oleh lembaga pelayanan anak Sekolah Minggu, serta evaluasi mengajar yang harus diadakan untuk mendapatkan data hasil pembelajaran untuk dijadikan pedoman perbaikan hasil di tahun ajaran berikutnya. Kelima, guru-guru sekolah minggu harus bisa menerapka metode mengajar sekolah minggu yang efektif dengan menggunakan musik disertai gerakan akan membuat murid lebih semangat belajar, dan metode mengajar tanya jawab mendorong anak unuk aktif selama proses belajar. Keenam, guruguru sekolah minggu belajar menggunakan media pendukung keefektifan mengajar dimana mereka menggunakan alat peraga dan juga ruang belajar yang harus dihias semenarik mungkin sehingga anak nyaman pada saat anak melaksanakan ibadah sekolah minggu. Ketujuh, guru-guru sekolah minggu jemaat GPdI El-Shaddai Makassar adalah seorang guru yang berkomitmen untuk mengajar.

\section{Kesimpulan}

Kompetensi guru Sekolah Minggu baik itu pedagogik dan kepribadian yang baik perlu mendapat dukungan dari pihak gereja. Gereja wajib memfasilitasi ruang Sekolah Minggu yang ramah anak. Kompetensi guru Sekolah Minggu perlu ditingkatkan melalui pelatihan-pelatihan storytelling, penggunaan alat peraga dan media, bahkan juga kompetensi sosial guru dalam mengoperasikan alat media yang sangat penting di masa Covid-19. Kompetensi guru 
Sekolah Minggu memberikan pengaruh nyata terhadap keefektifan mengajar anak Sekolah Minggu. Metode mengajar Sekolah Minggu adalah salah satu cara meningkatkan keefektivan mengajar pada anak. Anak-anak tertarik mengikuti Sekolah Minggu apabila ada nyanyian lagu, gerakan, dan pertanyaan kepada anak yang memberikan dampak pada keaktivan anak dalam belajar di dalam Sekolah Minggu.

\section{Rujukan}

Astika, M., \& Bunga, S. S. (2016). Hubungan Kompetensi Sosial Guru Kristen Terhadap Perkembangan Karakter Siswa: Tantangan Pendidikan Kristen Dalam Mencerdaskan Youth Generation. Jurnal Jaffray, 14(1), 63-76. https://doi.org/10.25278/jj71.v14i1.189

Bayoe, Y. V., Kouwagam, M. L., \& Tanyit, P. (2019). Metode Pembelajaran Melalui Film Superbook dan Minat Belajar Firman Tuhan Pada Anak Usia 6-8 Tahun. Jurnal Jaffray, 17(1), 141-156. https://doi.org/10.25278/jj71.v17i1.327

Darmawan, I. P. A., \& Priskila, K. (2020). Penerapan Storytelling Dalam Menceritakan Kisah Alkitab Pada Anak Sekolah Minggu. KURIOS (Jurnal Teologi Dan Pendidikan Agama Kristen), 6(1), 35-46.

Febriyona, C., Supartini, T., \& Pangemanan, L. (2019). Metode Pembelajaran dengan Media Lagu untuk Meningkatkan Minat Belajar Firman Tuhan. Jurnal Jaffray, 17(1), 123-140. https:/ / doi.org/10.25278/jj71.v17i1.326

Gunarsa, S. D., \& Gunarsa, Y. S. D. (2017). Psikologi Perkembangan Anak Dan Remaja. BPK Gunung Mulia.

Juanda, J. (2016). Pengaruh Kelas Pendalaman Iman Anak Lebak Arum (Piala) Terhadap Pertumbuhan Rohani Anak Usia 11-14 Tahun Di Kompleks Perumahan Lebak Arum Surabaya. Jurnal Teologi \& Pelayanan KERUSSO, 1(1), 51-56. https:/ / doi.org/10.33856/kerusso.v1i1.48

Karnawati, K., \& Mardiharto, M. (2020). Sekolah Minggu Masa Pandemi Covid 19: Kendala, Solusi, Proyeksi. Didache: Journal of Christian Education, 1(1), 13-24. https://doi.org/10.46445/djce.v1i1.291

Kristiono, T., \& Perdana, D. P. (2019). Hambatan Guru dan Pelayanan Sekolah Minggu di Gereja Kristen Jawa Jebres Surakarta. JURNAL TEOLOGI GRACIA DEO, 1(2), 90-100.

Latif, H. F. (2018). Pengaruh Pengajaran dan Persekutuan Terhadap Tingkat Pertumbuhan Rohani Anak dan Remaja. EPIGRAPHE: Jurnal Teologi dan 
Pelayanan

Kristiani,

$1(2)$,

119-138.

https:// doi.org/10.33991/epigraphe.v1i2.18

Richards, L. O. (2013). Pelayanan Kepada Anak-Anak. Kalam Hidup.

Riniwati, R. (2020). Pembinaan Guru Sekolah Minggu Untuk Mengajarkan Konsep Keselamatan Pada Anak. Evangelikal: Jurnal Teologi Injili Dan Pembinaan Warga Jemaat, 4(2), 186-194. https:// doi.org/10.46445/ ejti.v4i2.247

Ronda, D. (2011). Leadership Wisdom. Kalam Hidup.

Rosdiana, D. (2013). Pengaruh Kompetensi Guru Dan Komitmen Mengajar Terhadap Efektivitas Proses Pembelajaran Serta Implikasinya Pada Hasil Belajar Siswa Dalam Mata Pelajaran Ekonomi. Jurnal Penelitian Pendidikan, 13(2), Article

https://ejournal.upi.edu/index.php/JER/article/view/3433

Sabdono, E. (2016). Resurrecting Jesus Within Us. Rehobot Literature.

Saputra, Y. N. (2020). Penilaian Berbasis Test di Sekolah Minggu. Evangelikal: Jurnal Teologi Injili dan Pembinaan Warga Jemaat, 4(2), 156-166. https://doi.org/10.46445/ejti.v4i2.245

Sidjabat, B. S. (2019). Kerangka Kurikulum Pendidikan Agama Kristen Berbasis Karakter di Perguruan Tinggi. Jurnal Jaffray, 17(1), 73-90. https://doi.org/10.25278/jj71.v17i1.314

Supartini, T. (2017). Sudah Ramah Anakkah Gereja? Implementasi Konvensi Hak Anak Untuk Mewujudkan Gereja Ramah Anak. Jurnal Jaffray, 15(1), 1-30. https://doi.org/10.25278/jj71.v15i1.233

Supartini, T. (2020). Development of Learning Methods through Songs and Movements to Improve Children's Cognitive and Psychomotor Aspects. European Journal of Educational Research, 9(4), 1615-1633. https:/ / doi.org/10.12973/eu-jer.9.4.1615

Susilawati, N., \& An, D. N. (2017). Pengembangan Video Tutorial Pembuatan Silabus dan Rencana Program Pembelajaran Bagi Mahasiswa. Edudikara: Jurnal Pendidikan Dan Pembelajaran, 2(4), 364-372. https://doi.org/10.32585/edudikara.v2i4.70

Suwanto, S. (2019). Budaya Kerja Guru. Gree Publishing.

Usman, H., \& Akbar, P. S. (2008). Metodologi penelitian sosial. Bumi Aksara.

Widiyanto, M. A., \& Darmawan, I. P. A. (2019). Pengaruh Kompetensi Dan Kepuasan Mengajar terhadap Prestasi Kerja Guru Agama Kristen. Kelola: 


$$
\begin{aligned}
& \text { Jurnal Manajemen Pendidikan, } \\
& \text { https://doi.org/10.24246/j.jk.2019.v6.i2.p179-187 }
\end{aligned}
$$

Wijaya, H. (2017). Metodologi Penelitian Pendidikan Teologi. Sekolah Tinggi Theologia Jaffray.

Wijaya, H., Arismunandar, \& Gani, H. A. (2020). Trends in Educational Research about Social Attitudes Education and Learning: A Systematic Literature Review. Universal Journal of Educational Research, 8(12A), 7682-7693. https://doi.org/10.31219/osf.io/zep34

Yusuf, B. B. (2018). Konsep Dan Indikator Pembelajaran Efektif. Jurnal Kajian Pembelajaran Dan Keilmuan, 1(2), 13-20. 